$18: 626$

の可能性から，冠動脈造影を施行するとととしてきた． 今回，心㖪腫瘍症例の冠動脈造影を再検討したところ， 興味ある所見がえられた，従来粘液腫は卵円简から発生 することが多いと報告され，本報告でも同様であった が, 栄養血管が造影された場合には, その茎の存在部位 を推測するととが可能であった，とくに症例 7 のごと く, 複数の栄養血管が造影され，心房中隔後部に広沉な 茎が予測される場合には, 左房後壁を切除修復する必要 が予測できる，粘液腫再発の防止のためには心内膜を同 時に切除するととが必須であるが，左房壁のごとく筋層 がうすい場合には，心外膜のみが残ることとなり，その 修復を要する場合がある. 症例 7 では, 左房頂部, 大動 脈之上大静脈の間の左房壁を縫合する必要があった.

腫瘍染が認められたのは 3 例のみであったが, 腫瘍染 の程度, 形態により, 比較的固い粘液腫であるが, 軟く て, 非常にあるい腫瑒であるかを予測することが可能で ある. とくに塞栓症の既往をもつ症例では軟くて, ある い型のものが多く，比較的固い場合には塞栓症の既往が 明らかでなかった，てれらの臨床症状と，固い場合に
18巻 4 号 (1989)

は，腫瘍染がなく，あってもごくわずかであるととが多 いととが参考となる、症例 7 のごとき著明な腫瘍染があ り，軟い腫湯が予測される場合には，上くに慎重な手術 操作が要求される.

心外膜炎によるタンポナーデと診断され，加療されて いる症例の中には，症例 8 亿しめしたでとく, 冠静脈洞 の腫瘍による冠静脈のうっ滞によって発生しているもの が混在する可能性がある. 本症例が 7 年の経過を経てい るととを考慮すれば，相当の長期の経過をしめす症例が あることを注意すべきである。

\section{結語}

心臟腫瘍症例には冠動脈造影を施行すべきであり, 粘 液腫では, 腫崵の性状, 発育様式の診断に有用であり, 栄養血管が造影される場合には, 茎の存在部位, 範囲の 予測が可能で手術術式の決定に参考になる.

心タンポナーデをくり返す症例では, 冠静脈洞内腫瘍 の可能性があり, 冠動脈造影により, 腫瘍存在の診断と と屯に，病態の把握が可能となる.

\title{
183 収縮性心膜炎の外科治療における
}

新しい術中心機能評価法

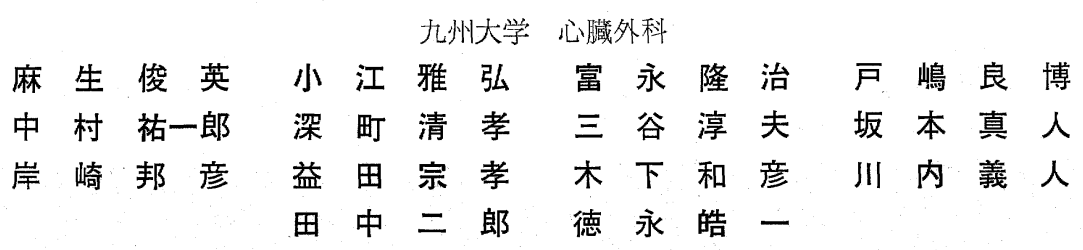

收縮性心膜炎の外科治療のポイントは肥厚, 硬化した 心膜を除去し，低下した心室コンプライアンスを改善す ることにある. しかし, 心室コンプライアンスを術中に 評価する手段がなかったため，どの範囲まで心膜を豩 離, 切除すべきかの判断は経験にたよるととが多かっ $た^{1,2)}$.

われわれは収縮性心膜炎 2 例に対し新しい心機能解析 法を忘用し，術中に心室コンプライアンスを測定した. その結果, 心膜の剶離範囲の決定や手術效果の判定に有 用であったので報告する.

\section{方法}

収縮性と拡張末期容積とがそれぞれ等しい駆出心拍と 等容性心拍との圧一容積ループが得られれば, 収縮性の 指標である $E_{\max }$ や有効拡張末期容積 $\left(V_{\mathrm{ed}}-V_{\mathrm{o}}\right)$ が測定 可能である ${ }^{4,5)}$. そこで術中, 電磁血流計にて大動脈血 流を測定し，その積分值から駆出期に拈ける左室容積の 変化量を求めた。 また，Millar 社製力テ先圧力計を上 行大動脈より左室へ逆行性に㨂入し左室圧を測定した. 左室容積の変化量と左室圧とから等容収縮期から等容弛 緩期までの駆出心拍の圧-容積軌跡を得た．駆出心拍の 左室圧波形よりそれと同じ拡張末期容積をすつ等容性駆 


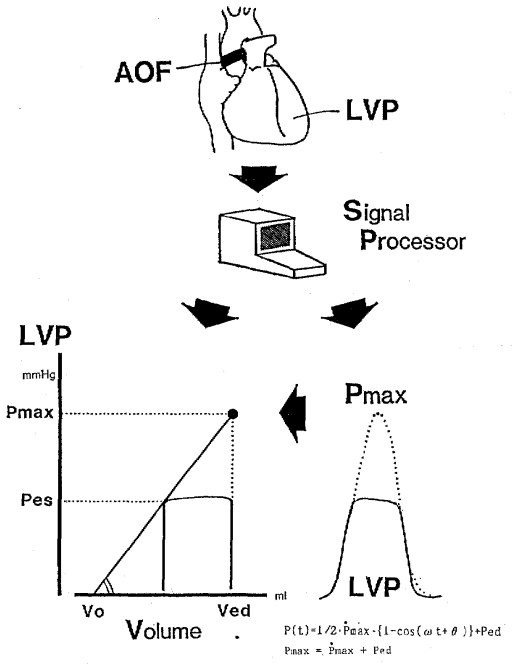

図 1 Principle and method

出心拍の最高到達圧 $\left(P_{\max }\right)$ を独自の方法で推定した ${ }^{3)}$. この $P_{\max }$ 加ら駆出心拍の圧-容積軌跡に引いた接線の 傾きが $E_{\max }$ である．また，容積軸上の切片 $\left(V_{0}\right)$ と拡 張末期容積 $\left(V_{\mathrm{ed}}\right)$ との距離が有效拡張末期容積 $\left(V_{\mathrm{ed}}-V_{\mathrm{o}}\right)$ である．そこで，術中に上大静脈あるいは下大静脈を閉 塞し心室容積を変化させて $V_{\mathrm{ed}}-V_{\mathrm{o}}$ と拡張末期圧との関 係をプロットして左室拡張末期圧一容積関係 (EDPVR) を得た（図 1 ).

\section{症例}

症例は 38 歳と 67 歳の男性である. NYHA 機能分類 は II 度と III 度であった．病悩期間はそれぞれ 14 年と 5 年であった，手術は胸骨正中切開にて到達し，心膜剝離 術を施行した. 1 例では横隔膜面，ならびに左室後側方 の心膜剝離のため人工心肺心停止に手術を行った.
結果

図 2 は心膜切除前後の EDPVR の変化を示してい る. 心膜切除により EDPVR は右下方に移動し心室コ ンプライアンスの改善がみられている.

\section{考察}

心拍出量は 1）収縮性，2）心室コンプライアンス, 3）心拍数，4）後負荷，5）前負荷の五つの因子によって 決定される. 図 3 は心室の圧-容積平面上に描いた駆出 心拍の圧一容積ループを示している. 心拍出量 (CO) は 心拍数 $(\mathrm{HR}), E_{\max }$ と平均動脈圧 $(\mathrm{MAP})$ ，および有効 抎張末期容積（ $\left.V_{\mathrm{e}}\right)$ より図中の式に示すように表され $ろ^{6)}$. したがって，CO，MAP，HRをある值に設定し， $E_{\text {max }}$ の測定值を代入すれば図の式より $V_{\mathrm{e}}$ が決定され る.たとえば，症例 1 に执いて心拍数が每分 70 ，平均 動脈圧が $70 \mathrm{mmHg}$ のもとで $2.5 \mathrm{l} / \mathrm{min} / \mathrm{m}^{2}$ の心係数を 得るためには $102 \mathrm{ml}$ の有効拡張末期容積 $\left(V_{\mathrm{e}}\right)$ が必要 となる．との $102 \mathrm{ml} の V_{\mathrm{e}}$ を得るために必要な左室 拡張末期圧が生理的範囲内にあれば収縮性心膜炎の心膜 剝離の目的は達せられたことになる。罒2における星印 （引）は $V_{\mathrm{e}}$ が $102 \mathrm{ml}$ で左室拡張末期圧が $10 \mathrm{mmHg}$ の点を表している. 症例 1 では心膜袔離によりての目的 が達せられたことがわかる，症例 2 では体外循環を用い ずに剝離を進め左室の後面，側面の剝離を残した時点で の EDPVR（ム）は改善傾向はあるものの不十分であ る，そこで，体外循環，心停止下に左室後面，および側 面の剶離を行った．EDPVR（口）は著明に改善したが 生理的な左室拡張末期圧にて心係数 $2.5 \mathrm{l} / \mathrm{min}$ を得るこ とはできないと判断された．本症例は術後 1 年の現在, NYHA 機能分類II度である.

このように本法を用いた剥離に伴うポンプ機能の変化

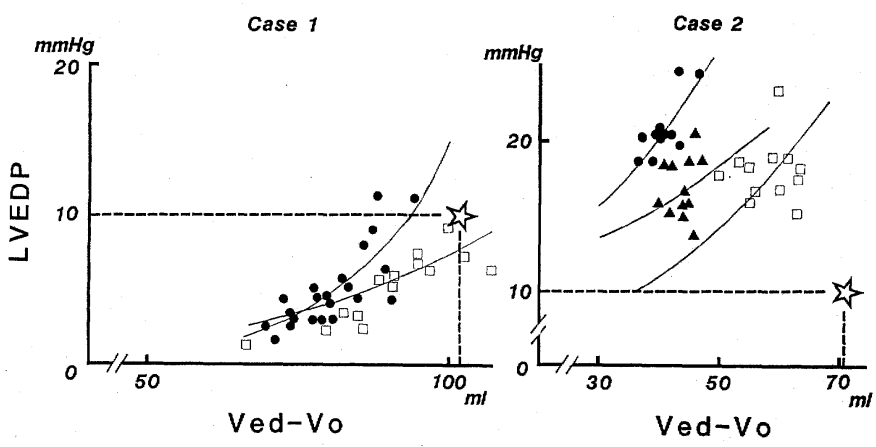

図 2 Evaluation of pericardiectomy 


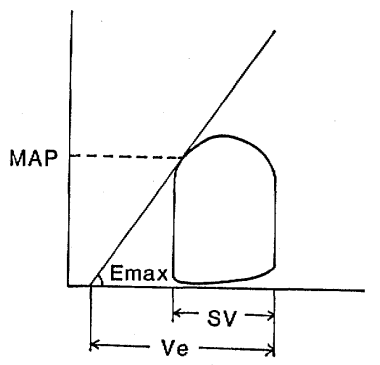

$\mathrm{CO}=\mathrm{S} \mathrm{V} \cdot \mathrm{HR}$

$=(\mathrm{Ve}-\mathrm{MAP} / \mathrm{Emax}) \cdot \mathrm{HR}$
症例 1 では，

$\mathrm{HR}=70 / \mathrm{min}$

$\mathrm{MAP}=70 \mathrm{mmHg}$

$\mathrm{Em} \mathrm{a} \mathrm{x}=1.8 \mathrm{mmHg} / \mathrm{ml}$

のとき,

C I $=2.5 \mathrm{~L} /$ min $/ \mathrm{m}^{2}$

とするためには，

$\mathrm{V}$ e $=102 \mathrm{ml}$

が必要である。

図 3 心膜の剝離範囲の決定

を評価するととができた．乙れにより心膜の剝離範囲が 十分であるか否か，さらに人工心肺の心膜剝離が必要で あるか否かの判断を下すととができる. したがって，心 膜の剝離範囲の決定や手術の効果判定化有益である之考 える.

\section{結論}

本法を用いて心膜剝離にとあなう心室コンプライアン スの変化が術中に評価された．本法は収縮性心膜炎の外
科治療における心膜の剝離範囲の決定や手術の効果判定 に有用之考える.

文 献 1) Walsh. T. J. et al.: J. Thorac. Cardiovasc. Surg. 83: 126, 1982. 2) McCauhan, B.C. et al.: J. Thorac. Cardiovasc. Surg. 89: 340, 1985. 3) Asou, T. et al. : Jpn. Circ. J. 51: 767, 1987. 4) Igarashi, Y. et al. Am. J. Physiol. 250: H685, 1986. 5) Asou, T. et al. Circulation 74 (Suppl. II) : 443, 1986. 6) Sunagawa, K. et al. : Am. J. Physiol. 14: H773, 1983

\section{前田 肇 数 野 博 今 脇 節 朗 吉 鷹 秀 範 堀 原 - *}

心のう液は心膜を介する物質移動の重要な産物であ る. その組織は心臟の代謝や病態を反映していると考え られるが，正常值さえいまだ明らかにされていない，そ こで，心のう液の組織分析を行い，生成機序を推定する とともに，疾患による差異があるか否かを検討した.

\section{対象と方法}

開心術を行った 109 例と尿毒症による心タンポナ ーデの 1 例の計 110 例を対象とした。它中隔欠損症 (ASD) 41 例，心室中隔欠損症 (VSD) 15 例，ファロー 四徴症 (TOF) 17 例, 僧帽弁狭窄症 (MS) 18 例, 僧帽 弁閉銷不全症（MR）6例 抢上び大動脈弁閉鎖不全症 (AR) 12 例であり，平均年齢はそれぞれ 18.6土16.5,
8. $0 \pm 9.7,5.0 \pm 4.0,45.7 \pm 11.0 ， 50.0 \pm 11.0$ および 47. $1 \pm 12.6$ 歳である. 尿毒症例は 44 歳の女性である.

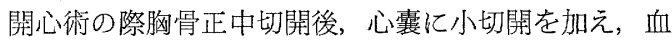
液が混入しないように心のう液を 5〜20 $\mathrm{ml}$ 採取した. 同時に採血した $20 \mathrm{ml}$ の静脈血加ら血清を遠心分離し た. 尿毒症例は心のう穿刺で心のう液を採取した．乙れ らの試料を日立自動分析機（716，706，702，706 D ) お よび Hyland 社製 Laser-Nephelometer $\mathrm{PDQ}^{\mathrm{TM}}$ に より組成分析した，組成分析は蛋白質，電解質，尿素 窒素, クレアチニン, 中性脂肪, ビリルビン, GOT, GPT, LDH, コレステロール, IgG, IgA, IgM など 30 項目, 分子量 23 から $1,000,000$ にわたる広範囲の物質 について行った。 さらに，10 例は高速液体クロマトグ 